\title{
MÁRIO DE ANDRADE AINDA VIVE? $O$ ideário modernista em questão
}

\section{Yvonne Maggie}

Daniel foi o primeiro classificado no mais difícil vestibular de uma universidade pública, o vestibular de medicina da Universidade Estadual do Rio de Janeiro (Uerj) em 2003, com a nota mais alta entre todos os candidatos. O jovem de 25 anos foi entrevistado pela Rede Globo de televisão no seu programa de domingo, o Fantástico. Sem medo das câmeras, com um sorriso largo e rosto moreno, cabelos cortados rente à cabeça, o jovem disse ter se declarado pardo na ficha de inscrição do primeiro vestibular das cotas para negros e pardos, instituídas por força de lei, porque vinha de uma família de "origem negra". Tendo uma bisavó negra, achava que não poderia se considerar branco e decidiu declarar-se pardo. Daniel pode ser considerado de aparência típica

Artigo recebido em janeiro/2005

Aprovado em abril/2005 brasileira, um Macunaíma, podendo escolher entre as categorias negro, pardo, preto, indígena ou mesmo branco e podendo ser visto também da mesma forma pelas outras pessoas. Na verdade, declarou sua cor porque os candidatos ao vestibular da Uerj em 2003, pela primeira vez em nossa história, foram induzidos a escolher entre duas categorias negro/pardo ou branco, pois se havia instituído $40 \%$ de cotas para negros e pardos, além de $50 \%$ de cotas para estudantes de escolas públicas. ${ }^{1} \mathrm{O}$ candidato em questão não precisava do sistema de cotas para entrar na universidade, pois foi o que teve o melhor desempenho entre todos os candidatos no vestibular. Ele já tinha se posicionado contra o sistema de cotas e assim como muitas pessoas que enviaram cartas aos jornais com suas opiniões depois que o sistema foi implantado em 2002, e mesmo quando foi instituído dois anos antes. ${ }^{2}$ 
Uma outra candidata com a mesma aparência "misturada" de Daniel, também entrevistada em outro programa de TV, disse que não se declarou negra ou parda com medo de ser considerada mentirosa, pois a lei diz que os candidatos devem firmar sua própria identidade, "sob as penas da lei”. Desolada por não ter obtido uma vaga, apesar de ter tido nota superior a muitos que se declararam negros ou pardos, disse que pensava em entrar na justiça para fazer valer o seu direito.

Qual o significado desse acontecimento, a mudança de uma lei, e como pode afetar a estrutura de nossa sociedade baseada em um sistema de valores que não aposta na oposição, mas na complementaridade, no que une e não no que separa? ${ }^{3}$

Minha intenção neste trabalho é refletir sobre a hipótese de que se inicia uma espécie de terremoto na maneira pela qual o Brasil pensa o Brasil no alvorecer do século XXI. Com a recente legislação sobre cotas para negros nas universidades e no serviço público federal a idéia de nação misturada da "fábula das três raças" parece ter sido questionada, cedendo lugar à noção de uma nação dividida entre negros e brancos.

Pela primeira vez na nossa história desde os anos de 1920, a elite brasileira parece ter lançado por terra as bases do pensamento que permitiu a criação de nossa cultura mais radicalmente nacional e cosmopolita. O ideário de brasilidade modernista de Mário e Oswald de Andrade, de Paulo Prado e Sérgio Buarque de Holanda, de Gilberto Freyre e Di Cavalcanti, de Tarsila do Amaral e Anita Malfati está sob suspeita. Todo o esforço empreendido nos anos de 1930 para positivar a mestiçagem parece estar sendo posto a baixo. Os números das desigualdades raciais, divulgados recentemente por Ricardo Henriques e Roberto Martins do Instituto de Pesquisas Econômicas Aplicadas (Ipea) por ocasião da preparação da III Conferência Mundial das Nações Unidas ${ }^{4}$ ocorrida em Durban, na África do Sul, em 2001, passaram a constituir uma "verdade" da nação.

O Brasil deve se pensar, agora, a partir das categorias "negro" e "branco", construídas para desvendar a nossa estrutura social, e não a partir de seu gradiente de cor que aproxima os pólos negro e branco. Os números descrevem uma sociedade partida entre negros e brancos, como o faz também a introdução de cotas, ou reservas de vagas, para "negros" na função pública federal e nas universidades do Estado do Rio de Janeiro. Há, contudo, uma pergunta que paira no ar: por que só agora esses números, já conhecidos pelo menos desde os anos de 1950 com o Projeto da Unesco, ${ }^{5}$ e que foram mais estudados nos anos de 1970, com os trabalhos de Nelson do Valle Silva (1978), Carlos Hasenbalg (1979) e Oliveira et al. (1983), saíram do círculo restrito dos poucos especialistas do tema e ganharam a mídia, transformando-se em contra-discurso ou em negação de uma versão da nossa nacionalidade que até ontem estava presente inclusive no discurso dos militantes dos movimentos negros?

Cabe indagar: será que a nação segregada nos números é a mesma presente nos bairros das periferias, na mente dos cantadores, nas salas de aula desconfortáveis dos cursos pré-vestibular do Movimento do Pré-Vestibular para Negros e Carentes (PVNC)? Há ainda alguma forma de interpretar o mito da democracia racial como um mapa para a ação social e compromisso com o igualitarismo como fez Peter Fry (2000) ao discutir as interpretações de Pierre Bourdieu e Loic Wacquant (1998) sobre as ações afirmativas no Brasil? Há como servir a dois senhores, de um lado apostar na mistura, no que une, e, de outro, no que é diverso e separa? Esses dois modelos vêm sendo discutidos e destrinchados por Peter Fry em inúmeros de seus trabalhos desde o clássico "Feijoada e soul food" nos anos de 1980 até os recentes artigos sobre as conseqüências das políticas coloniais, reunidos no livro A persistência da raça, Fry (2005b). ${ }^{6}$

Neste trabalho, volto-me para os nossos heróis fundadores porque acredito ser correto retomar o debate de onde começou. É com certeza difícil discorrer sobre essas transformações que agora se apresentam carregadas de muita moral "politicamente correta". Mas é impossível se calar diante desses acontecimentos. Essa nova versão 
de um Brasil que é imaginado ou deveria ser imaginado como uma nação segregada em duas "raças" tem seduzido muitos adeptos não só entre os movimentos sociais como entre os bem pensantes de nossa sociedade. ${ }^{8}$

\section{Macunaíma e o Manifesto antropófago}

Em 1928, Mário de Andrade publicava o clássico Macunaíma: um herói sem nenhum caráter dedicado a Paulo Prado, que no final do mesmo ano publicaria o seu Retrato do Brasil. O romance é uma história baseada em lendas e mitos brasileiros. ${ }^{9}$ O personagem central, Macunaíma, foi construído a partir da descrição feita pelo naturalista alemão Theodor Koch-Grünberg em Vom Roroima zum Orinoco (Do Roraima ao Orenoco) publicado, em cinco volumes, entre 1916 e 1924.

Mário não estava só nesta empreitada que foi a de sua geração. Seu argumento, no entanto, não surgia do nada. É preciso lembrar que se ancorava em idéias enraizadas na nossa cultura já no século XIX, basta pensar na tese de Carl F. von Martius, Como se deve escrever a bistória do Brasil, vencedora do concurso do Instituto Histórico e Geográfico Brasileiro em 1836. ${ }^{10}$ Esta monografia marcou o futuro de nossa historiografia ao descrever nossa história a partir da mescla de brancos, negros e índios na "raça brasileira" usando a metáfora do encontro entre três rios. O argumento da "raça" era tão forte que Mário numa primeira versão de Macunaíma teria optado pelo epíteto de "herói de nossa raça". Só mais tarde é que mudou para "herói de nossa gente". No entanto, tomarei aqui o romance como um marco para pensar o que muda e o que permanece no nosso ideário de nação nos últimos tempos. ${ }^{11}$

Sei também que entre 1928 e 2000 muitas coisas mudaram e não se pode apenas dizer que o modernismo é nossa única herança, mesmo porque havia diferentes modernistas e diferentes perspectivas já naquela época. Não estou dizendo que existem apenas os "adeptos da brasilidade" e os "contra", como alguns podem interpretar. O ideário modernista mudou nesses trinta anos e influenciou, de forma diversa, muitas gerações desde a década de $1920 .{ }^{12}$ A contestação desse ideário também foi surgindo ao poucos com a persistente crítica ao "mito da democracia racial" empreendida pelos movimentos negros desde pelo menos os anos de 1950. Não vou aqui descrever esse processo que foi tão bem analisado por Fabiano Dias Monteiro (2003) em sua dissertação de mestrado. Neste trabalho vou deixar de lado o longo processo que gerou os dois modelos e buscar, carregando nas tintas, opor duas versões que estão sendo postas na mesa neste início do século XXI.

Voltando ao romance Macunaíma, embora seja uma história já clássica, não custa refrescar a memória. Mário começou o livro, que chamou de poema ou rapsódia, relatando o nascimento do nosso herói:

No fundo do mato-virgem nasceu Macunaíma, herói de nossa gente. Era preto retinto e filho do medo da noite. Houve um momento em que o silêncio foi tão grande escutando o murmurejo do Uraricoera, que a índia tapanhumas pariu uma criança feia. Essa criança é que chamaram de Macunaíma.

Já na meninice fez coisas de sarapantar. De primeiro passou mais de seis anos não falando. Si o incitavam a falar exclamava:

- Ai que preguiça!...

e não dizia mais nada.

...As mulheres se riam muito simpatizadas, falando que "espinho que pinica de pequeno já traz ponta," e numa pajelança Rei Nagô fez um discurso e avisou que o herói era inteligente (Andrade [1928] 1984, p. 9).

A história é longa e conta como Macunaíma, nascido preto, de mãe índia, virou branco quando foi parar na cidade depois de sair da mata virgem. O encontro de Macunaíma com a cidade é belíssimo e descreve, às avessas, o espanto dos colonizadores diante da cultura e da sociedade indígenas. É na cidade que se desenrola a trama principal. Macunaíma busca a muiraquitã e no decorrer da narrativa vira, além de branco, inseto, 
peixe e até mesmo um pato. Decide travestir-se de francesa para seduzir Venceslau Pietro Pietra, o gigante Piaimã, comedor de gente, companheiro de uma caapora velha chamada Ceiuci, também antropófaga e muito gulosa, para reconquistar a muiraquitã. Resolve procurar o terreiro de Tia Ciata e lá pede a Exu que o auxilie a reaver a muiraquitã. A descrição do terreiro é maravilhosa e tia Ciata - uma mãe-de-santo que ficou na história dos cultos afro-brasileiros - manda Exu castigar Venceslau Pietro Pietra em cena ontológica. Macunaíma procura até uma bolsa de estudos para ir para a Europa, e o romance termina como um mito de origem, descrevendo como o herói virou brilho bonito, mas inútil, de estrela da constelação da Ursa Maior.

Macunaíma é uma ficção escrita em seis dias. Mário de Andrade revelou a sua descoberta do herói em um prefácio que nunca chegou a publicar junto com o romance. Telê Porto Ancona Lopez, em edição crítica do romance, transcreve o trecho em que Mário revela a sua intenção e o significado que deu à sua descoberta:

O que me interessou por Macunaíma foi incontestavelmente a preocupação em que vivo de trabalhar e descobrir o mais que possa a entidade nacional dos brasileiros. Ora depois de pelejar muito verifiquei uma coisa que me parece certa: o brasileiro não tem caráter. Pode ser que alguém já tenha falado isso antes de mim, porém, a minha conclusão é uma novidade para mim porque tirada da minha experiência pessoal. E com a palavra caráter não determino apenas uma realidade moral não, em vez, entendo a entidade psíquica permanente, se manifestando por tudo, nos costumes, na ação exterior, no sentimento, na língua, na História, na andadura, tanto no bem como no mal. O brasileiro não tem caráter porque não possui nem civilização própria nem consciência tradicional. Os franceses têm caráter e assim os iorubas e os mexicanos. Seja porque civilização própria, perigo iminente, ou consciência de séculos tenham auxiliado, o certo é que esses uns têm caráter. Brasileiro não. Está que nem o rapaz de 20 anos: a gente mais ou menos pode perceber tendências gerais, mas ainda não é tempo de afirmar coisa nenhuma. [...] Pois quando matutava nessas coisas topei com
Macunaíma no alemão de Koch-Grünberg. E Macunaíma é um herói surpreendentemente sem caráter. (Gozei). (Andrade, 2001, p. 169).

Mário e a geração modernista pensavam que a história era ancorada no mais profundo inconsciente da nossa sociedade, a ponto de Oswald chamar o romance de a Odisséia brasileira. Será que pensavam mal? Teria sido toda essa invenção de um país misturado, mestiço e onde o mito de igualdade entre as "raças" estava no cerne da utopia, uma ficção de uma elite que não conhecia e nem via o que estava à sua volta? Seria esta uma invenção ou mito, no sentido de farsa ou mentira, que ganhou o mundo, transformando o nosso destino de uma sociedade inviável, porque mestiça, em desiderato e fonte de todo o espanto?

Pensavam os modernistas e muitos depois deles que era preciso transformar os campos de trigo em verdes plantações de abacaxi ou como disse Mário, em carta de 1940, ao jovem poeta Alphonsus de Guimaraens Filho referindo-se a versos de "Lume de estrelas":

Com o caso do "canavial" já não concordo com você. Si trigo é mais universal (não há dúvida), o é numa universalidade perigosa, Bíblia-via-Europa. "Canavial" é exótico em Rilke? Não há dúvida e é isso que me interessa prá humanidade de você, pra não-esteriotipação de você: é que se você tivesse falado sem vir através de canaviais, ou cafezais, ou de terras de ferro, isso seria sua humanidade, sua Minas, seu Brasil, sua América. "Trigo" é, no caso, um remígio do condor. Se observe bem e você verá que é (Andrade e Bandeira, 1974, pp. 16-17).

Era preciso também gostar de ser brasileiro por acaso e por escolha e não querer ser outro. Era preciso descobrir o universal no nosso particular para transformá-lo em universal ou como dizia o próprio Mário:

Veja bem: abrasileiramento do brasileiro não quer dizer regionalismo nem mesmo nacionalismo Brasil pros brasileiros. Não é isso. Significa só que o Brasil pra ser civilizado artisticamente, entrar no concerto das nações que hoje em dia dirigem a 
Civilização da Terra, tem de concorrer com esse concerto com a sua parte pessoal, com o que o singulariza e individualiza, parte essa única que poderá enriquecer e alargar a Civilização (Inojosa, apud Moraes, 1999).

Mais contemporâneo não poderia ser e diante de tanta moral politicamente correta, Mário parece estar discutindo com aqueles que hoje querem pensar a partir do que aqui é falta, ausência, vazio em comparação com outras sociedades ditas civilizadas. A proposta modernista imaginava uma nação que tinha como singularidade a sua forma de lidar com as diferenças. Manuel Bandeira em sua Apresentação da poesia brasileira conta como Mário pensava a estética e a brasilidade. Sobre o tema da brasilidade diz Mário: "Só sendo brasileiro, isto é, adquirindo uma personalidade racial e patriótica (sentido físico) brasileira é que nos universalizaremos, pois que assim concorreremos com um contingente novo, novo assemblage de caracteres psíquicos para o enriquecimento do universal humano" (Mário, apud Bandeira, s.d., p. 127).

O modernismo foi um movimento estético que tinha uma maneira toda própria de pensar a mistura e a busca de uma identidade que não fosse aquela do universalismo iluminista, mas que fosse universal. Em nome da afirmação radical de nossa identidade, Oswald de Andrade assinou o manifesto do grupo no mesmo ano da publicação de Macunaíma, 1928, o Manifesto antropófago que resumo aqui, com pena de não poder mostrá-lo na íntegra:

Só a Antropofagia nos une. Socialmente. Economicamente. Filosoficamente. [...].

Única lei do mundo. Expressão mascarada de todos os individualismos, de todos os coletivismos. De todas as religiões. De todos os tratados de paz.

Tupi, or not tupi that is the question (Andrade, 1978, p. 13).

Queremos a Revolução Caraîba. Maior que a Revolução Francesa. A unificação de todas as revoltas eficazes na direção do homem. Sem nós a Eu- ropa não teria sequer a sua pobre declaração dos direitos do homem (Idem, p. 14).

Nunca fomos catequizados. Fizemos foi Carnaval. O índio vestido de senador do Império. Fingindo de Pitt. Ou figurando nas óperas de Alencar cheio de bons sentimentos portugueses (Idem, p. 16).

Antes dos portugueses descobrirem o Brasil, o Brasil tinha descoberto a felicidade (Idem, p. 18).

Era preciso descobrir a felicidade, ou seja, aquilo que nos tirava do destino trágico que nos impunha a dominação européia. Ainda não tínhamos tido a experiência da Segunda Guerra Mundial e nem tampouco do holocausto, e a declaração dos direitos do homem, citada no manifesto, era a da Revolução Francesa, considerada pobre pelos jovens e rebeldes intelectuais que se empenharam em desvendar esta idéia de uma nação misturada e que estava unida pela antropofagia dos Tupi que comeram o bispo Sardinha e com ele a Europa vista daqui.

Mas terá sido esta uma quimera de um grupo da elite que estava ausente da nossa realidade? Gilberto Freyre ([1933] 1995) foi um dos que estavam na trilha modernista e Casa-grande e senzala teve a primeira edição revista por Mário de Andrade. ${ }^{13}$ Era preciso transformar o país do pesadelo do conde Gobineau, ${ }^{14}$ que só via um fim trágico para tanta mistura, em uma utopia que nos colocaria em pé de igualdade com a Europa de Descartes. ${ }^{15}$ Falo aqui do "pesadelo de Gobineau", porque ele é quase um ícone de uma geração de adeptos do darwinismo racial, ${ }^{16}$ que jogou todas as suas fichas na idéia de que um país de "raças" mistas era inviável. Esse não era apenas o seu pesadelo, mas o grande fantasma que atormentou uma geração de pensadores do século XIX e que volta aqui e ali a assombrar ainda no século XX. Parece que o pesadelo renasce nessa grande mudança do século que começamos a viver. Afinal, a versão de um país dividido em brancos e negros é uma versão contemporânea da idéia de que a mistura é ruim e nos torna inviáveis.

Assim, uma geração de escritores e artistas pintou o Brasil da Mulata, de Di Cavalcanti, ${ }^{17}$ do 
Abapurú e da Negra, de Tarsila do Amaral. ${ }^{18}$ E algumas gerações depois deles continuaram pensando e inventando um país que não teme esta mistura e faz dela a delícia e a dor de ser o que somos. Não vou nomear todos, mas não se pode esquecer dos Concretos, e, sobretudo de Augusto de Campos e seu poema "Luxo". E o que dizer então do movimento tropicalista e daqueles jovens dos anos de 1960 que até hoje compõem canções que falam do nosso paradoxo de ser Haiti e não ser o Haiti. ${ }^{19}$ Também não se deve esquecer do clássico filme de Joaquim Pedro de Andrade que, em 1969, faz uma releitura de Macunaima, transformando o livro em obra cinematográfica que revela sua contemporaneidade. E o que dizer então dos trabalhos de Luiz Alphonsus O conceitual caboclo $^{20}$ e Índia e mato - paródia e metáfora da $\mathrm{Ne}$ gra de Tarsila - se não fosse essa interpretação do Brasil inaugurada por Mário de Andrade e os modernistas na década de 1920.

Outros percorreram os caminhos de Mário nas suas viagens do Turista aprendiz. ${ }^{21} \mathrm{O}$ mesmo Hermano Vianna (1995) já havia revelado histórias fantásticas da construção do samba no Rio de Janeiro. A partir da descrição do encontro, em 1926 de Gilberto Freyre, Sérgio Buarque de Holanda, Pedro Dantas, Heitor Villa Lobos e Luciano Garret com Patrício, Donga e Pixinguinha, imortalizados por seus apelidos no panteão da música popular brasileira, Hermano Vianna nos leva a descobrir o mistério do samba. O "encontro" ocorreu bem antes da publicação de Casa-grande e senzala (1933) e Raízes do Brasil (1936), livros que foram fundamentais para a definição da identidade moderna brasileira. Redescoberto por Hermano Vianna (1995) no livro O mistério do samba, hoje referência fundamental, esse encontro é um achado para se compreender os caminhos traçados pela história do samba e de nossa identidade.

Não se pode esquecer também Roberto DaMatta em toda a sua obra, que se diz herdeira de Sérgio Buarque de Holanda, e especificamente em sua contribuição toda particular no seminário "Multiculturalismo e racismo", organizado pelo Ministério da Justiça e que contou com a presen- ça do então presidente Fernando Henrique Cardoso em Brasília no ano de 1996. ${ }^{22}$

Neste seminário ouviu-se pela primeira vez os ecos do debate entre essas duas concepções de nação. Aqueles que propugnavam uma nação que tem como mito e desejo uma sociedade igualitária, em que a "raça" não seja tomada como característica de distinção e desigualdade. Deste lado estavam os que se identificam e identificam a nossa brasilidade em Macunaíma. Fábio Wanderley Reis (1997), na conferência intitulada "Mito e valor da democracia racial", e Roberto DaMatta (1997), na palestra "Notas sobre o racismo à brasileira", defenderam esta posição Do outro lado estavam aqueles que descreviam este desiderato da nossa nacionalidade como falsa consciência, como falta, como o que nos falta porque comparam a nossa maneira de pensar a diferença com outras sociedades que pensam "raça" a partir da oposição e não da mistura. Esses últimos rompiam com o mito Macunaíma, que viam como ilusão, e entre eles estavam os muitos pesquisadores norte-americanos e alguns brasileiros ao lado de militantes novos e históricos.

Entre os pesquisadores brasileiros que propõem tratar desigualmente os desiguais, destaco a participação de Antonio Sergio Guimarães, que desde então escreve sobre o tema e que, nesse seminário, expôs de forma muito cartesiana os pressupostos deste tipo de engenharia social e de sua aplicabilidade no Brasil. Mas havia outros como Thomas Skidmore (1997), Carlos Hasenbalg (1997), Angela Gilliam (1997), Anthony Marx (1997) e George Reid Andrews (1997). Ativistas de movimentos negro e o senador Abdias do Nascimento, que não foi convidado para a mesa, da platéia, faziam inúmeras intervenções se posicionando ao lado desses últimos. ${ }^{23}$

Sem dúvida o debate que se iniciou no final dos anos de 1990 não apagou de jeito nenhum as vozes dos que ainda se pautam pela versão da fábula das três raças como mito fundante da nação brasileira. Poderia ir listando e me lembrando de muitos que beberam na fonte do modernismo ou que foram buscar inspiração na escuta sensível 
dos muitos negros, morenos, mulatos, escuros, alvos, claros, marrons etc. que vivem esses encontros entre classes nos muitos rituais existentes na nossa sociedade.

Terá sido todo esse esforço e muitos livros inesquecíveis na nossa memória escritos em vão? Teriam sido seus autores apenas copiadores de uma mensagem que acabou como ideologia, transfigurando-se em refúgio de uma elite racista, como dizem muitos hoje? A dúvida e a pergunta não são infundadas. Hoje, o mito Macunaíma está sob severa crítica, pois inventando uma nação dividida entre negros e brancos, e destruindo aquele herói misturado e plástico com políticas de Estado que exigem a classificação bi-polar, apresenta-se em seu lugar um outro conceito de nação. Quem ousaria criticar Mário de Andrade? Parece que os que querem inventar um Brasil dividido em negros e brancos estão, sem se aperceber, muitas vezes destronando o mito Macunaíma, pois este funda uma nação baseada na mistura, na plasticidade desta mistura e na possibilidade de ser índio, branco e preto ao mesmo tempo. O presidente Fernando Henrique Cardoso em mensagem do dia 21 março de 2001, dia Internacional pela Eliminação da Discriminação Racial, contribuiu para esse destronar de nossa maneira toda particular de combater o racismo, porque querendo instrumentos para diminuir a exclusão social jogou fora o bebê com a água do banho ao dizer: "Não é fácil desmantelar estruturas mentais e institucionais fortalecidas durante séculos de escravidão, exclusão social e visões românticas de "democracia racial'. Há ainda os que usam adjetivos mais fortes para criticar essa matriz do universalismo como o fez Ricardo Henriques em entrevista concedida a $O$ Globo em 21/4/2002:

[...] é romper com a matriz republicana francesa. Todos nós fomos culturalmente educados e a grande maioria estudou numa base dessa grande matriz francesa universalista, que acha que o imperativo da igualdade é a melhor matriz para fazer qualquer intervenção, tratando todos por iguais. Esta é a estratégica mais cínica de lidar com o problema.
Tudo leva a crer que os revisores dessa legião de fundadores da brasilidade parecem estar propondo mudanças radicais naquela concepção de nação misturada e formada da mistura, que é plástica e ambígua na classificação e autoclassificação, em nome do combate ao racismo, disto que chamam de ideologia racial brasileira e em favor do fim das iníquas desigualdades raciais. As cotas para negros são um dos pilares que sustenta essa reorientação do projeto de nação que parece estar em curso. São, basicamente, duas as principais idéias que estão subjacentes às propostas dos revisores da brasilidade modernista:

- Construir uma nação dividida entre "raças" que se opõem - negra e branca -, e passar da idéia de integração para um ideário de separação sob a bandeira da "diversidade".

- Abandonar o ideal da democracia liberal francesa, pelo liberalismo da democracia norteamericana, propondo tratar desigualmente os desiguais e tomar o "mito da democracia racial" como ideologia que mascara a realidade.

Essa mudança de rumo de um projeto de nação não se faz sem riscos. A mudança é radical porque toma o que era próprio da nossa maneira de tratar a diferença como algo espúrio e que deve ser extirpado mediante políticas públicas como, por exemplo, com as cotas para negros no serviço público e em instituições públicas de ensino superior. A versão que dá origem a esta política de combate à desigualdade parece não só suspeitar de Macunaíma. Ela aniquila Macunaíma porque sendo política de Estado obriga as pessoas a se definirem não nos moldes de nosso herói fundador, mas como negro ou branco, e sendo política de Estado afeta a sociedade como um todo. A nova política de cotas adotada em muitos níveis das instituições federais, nas universidades públicas do Estado do Rio de Janeiro e em muitas outras universidades públicas do país, obriga as pessoas a se identificarem sem nenhuma dúvida entre estes dois pólos: ou negro ou não negro. ${ }^{24}$

O Governo Federal enviou em 2004 para o Congresso Nacional um projeto de lei que institui 
cotas para negros e estudantes de escolas públicas nas universidades federais. O projeto ainda está tramitando ao lado de outros vinte que já estavam lá tratando do mesmo tema. O ministro da Educação tomou os cuidados necessários para que a política de cotas raciais e sociais fosse discutida no Congresso Nacional, pelos representantes do povo.

Mas as cotas já tinham sido adotadas pelo Ministério da Educação por meio da portaria ${ }^{\circ} 30$ de 12 de agosto de 2004, como política de Estado. A portaria cria o critério "raça/cor" para a concessão do benefício do Financiamento ao Estudante de Ensino Superior (Fies). O Fies é um empréstimo destinado a custear as mensalidades de estudantes de instituições de ensino superior particulares esse crédito existe há muitos anos. Até agora o critério de concessão era a pobreza ou renda. Com a nova portaria o estudante que preenche o formulário responde ao quesito - "raça/cor". Se a resposta for "negra", terá 20\% a mais de chances de ganhar o benefício. O candidato que for selecionado para a entrevista final terá de apresentar "a certidão de nascimento do pai e/ou da mãe, na qual conste, em pelo menos uma delas, informação de que o(a) genitor(a) é da raça/cor negra".

Recentemente o MEC, por intermédio do Conselho Nacional de Educação, exarou outro documento importantíssimo e muito pouco debatido também, as Diretrizes curriculares nacionais para a educação das relações étnico-raciais e para o ensino de história e cultura afro-brasileira e africana. José Roberto Pinto de Góes (2004) foi o primeiro a nos alertar sobre elas em recente artigo n'O Globo. As diretrizes dizem que, conforme "alerta o movimento negro", aqueles que reconhecem sua ascendência africana são negros (pretos e pardos). Ou seja, as escolas devem ensinar o sistema de classificação racial adotado pelo "movimento negro".

A política de cotas é uma política pública que tem conseqüências lógicas que afetam a sociedade como um todo no presente e também o seu destino. A primeira é a necessidade de definir aqueles que serão objeto do benefício. Por isso a Universidade de Brasília exigiu as tais fotografias no ato da inscrição e a portaria do Fies, a certidão de nascimento com a "raça" do genitor(a). A segunda é a necessidade de educar a população para "a consciência" da "raça". Essas diretrizes são, portanto, necessárias para a criação de uma educação racializada e na qual o "movimento negro" tenha uma participação ativa. A terceira conseqüência é a idéia de orgulho étnico. Depois se pode imaginar uma escola dividida entre brancos e negros..$^{25} \mathrm{O}$ cenário mais próximo é o de um país dividido.

O modelo estatístico do IBGE, que vem pesquisando há pelo menos cem anos o lugar social da população brasileira, optou por um caminho que respeitava a ambigüidade de nosso sistema. As categorias ("preto", "pardo", "branco," "amarelo" e "indígena") adotadas nas estatísticas oficiais eram menos radicalmente opostas a Macunaíma porque permitiam a inclusão de um maciço grupo de pardos, misturados de toda a sorte, que podiam eventualmente migrar para branco ou para preto. Na versão que derruba Macunaíma não haverá outra escolha possível a não ser entre "branco" e "não branco". ${ }^{26}$

Como teria sido possível esta guinada tão profunda no ideário que marcou a nossa história do século XX? Como puderam essas propostas de mudança ser aceitas tão rapidamente, inclusive pela mídia, a ponto de terem sido tema das agendas políticas dos candidatos nas eleições presidenciais de 2002 e terem conquistado grande parte da elite contemporânea dos bem-pensantes? Estarão as pessoas que foram seduzidas por estas políticas conscientes de que estão na trajetória de destruição do ideário modernista?

É difícil descobrir as razões da mudança e mais difícil ainda imaginar que o ideário modernista pudesse ser tão rapidamente descartado. Será que realmente foi lançado por terra? Será que os proponentes das políticas de cotas se percebem como contestadores do ideário modernista? Apesar de querer acreditar naqueles que afirmam que nada mudará porque somos o que somos e vamos deglutir tudo isso à nossa maneira, não há como deixar de pensar que as mudanças propostas poderão afetar as bases do ideário modernista. 


\section{Agora é preciso traçar um pouco dessa história}

Em a Ilusão do concreto (1991), descrevi as preocupações que afligiam os pesquisadores do tema e muitos militantes ao longo dos anos de 1970 e 1980. Com dados levantados por ocasião dos eventos do centenário da Abolição da Escravatura, afirmei que a preocupação central dos bem-pensantes àquela época era com o que se chamava cultura negra e não com as desigualdades raciais. Descrevi o paradoxo de nosso sistema de classificação racial que embora baseado no gradiente de cores não deixa de mencionar a oposição, seguindo o fio condutor tecido por Oracy Nogueira (1985) em 1950, Moema de Poli Teixeira (1986) na década de 1980 e muitos outros antropólogos que nesses anos de 1980 descreveram um Brasil da mistura. ${ }^{27}$

Nas décadas de 1970 e 1980 um grupo de estudiosos do tema estava preocupado em estimular novos pesquisadores a mergulhar no estudo sobre desigualdades raciais e sobre o racismo. Esse grupo, liderado por Carlos Hasenbalg (1979) e Nelson do Valle Silva (1978), refletia sobre as razões do silêncio na literatura sociológica de então a respeito do racismo e das desigualdades raciais. Segundo o grupo, tal silêncio teria sido produzido pela visão herdada de Florestan Fernandes (1965) que considerava o racismo uma sobrevivência do passado escravista e acreditava que à medida que a sociedade se tornasse mais desenvolvida o racismo tenderia a desaparecer. Assim sendo, a pesquisa sobre o tema se apagou do cenário das ciências sociais que enfatizou os aspectos culturais herdados desse passado.

Impressionada também com os números das desigualdades raciais voltei-me para a pesquisa sobre os mecanismos produtores dessas desigualdades e afirmei que era o medo de falar naquilo que opõe e separa, ou seja, em brancos e pretos, o que dificultava o avanço das pesquisas Os meus dados, recolhidos em ampla pesquisa qualitativa, reforçavam a hipótese de que no Brasil preferimos pontes a margens no dizer clássico de Rober- to DaMatta. ${ }^{28}$ Considerei os dados levantados no ano do centenário como indício de que o Brasil poderia ter algo a ensinar ao mundo, sobretudo diante das trágicas guerras étnicas que assolavam a Europa Oriental:

A explosão do racismo no seio das sociedades do primeiro mundo, que esperavam ter superado suas divergências "étnicas" e diferenças sociológicas, está fazendo com que mais e mais estudiosos se voltem para a questão. Talvez essa influência consiga sensibilizar os intelectuais brasileiros (Maggie, 1991, p. 105).

Naquela época, porém, duvidei de Mário de Andrade. Pensei que a recusa em falar das desigualdades sociais e raciais e a insistência no discurso sobre uma cultura negra significavam que as idéias que marcaram a minha juventude e os meus primeiros escritos estavam servindo para deixar cegos os brasileiros diante do racismo presente no nosso cotidiano. Estariam enganados os jovens antropólogos dos anos de 1970, que em outras viagens de aprendizagem como etnógrafos descobriram um Brasil que se caracterizava por uma cultura da mistura, do encontro entre desiguais, nos terreiros de umbanda (Maggie, [1975] 2001), na "Feijoada e soul food" (Fry, 1983), no samba (Goldwasser, 1975) ou em prédios da Utopia urbana em Copacabana (Velho, 1971)?

Busquei caminhos para sair desse impasse que angustiava uma geração de antropólogos seguidores das linhas traçadas por Mário de Andrade. Minha primeira providência foi chamar mais parceiros para o debate, formando, no Laboratório de Pesquisa Social do Instituto de Filosofia e Ciências Sociais (IFCS) da Universidade Federal do Rio de Janeiro, uma geração de novos pesquisadores interessados no estudo da "questão racial". Com essa equipe de estudantes e outras antropólogas do Rio Janeiro e de São Paulo já tínhamos iniciado em 1988 uma ampla pesquisa qualitativa sobre o ano do centenário da Abolição. ${ }^{29} \mathrm{Um}$ dos interessantes resultados dessa pesquisa, além, é claro, dos artigos e das teses que dela se originaram, foi o de ter estimulado muitos 
estudantes a se dedicarem ao tema, a concluírem seus estudos na graduação e prosseguirem a carreira acadêmica no mestrado e no doutorado. Com apoio da Fundação Rockefeller, organizei em 1994, no IFCS, o Programa Raça e Etnicidade, trazendo pesquisadores brasileiros e de muitos outros cantos do mundo para discutirem e repensarem a questão. Ao longo desses anos revisitei os meus primeiros escritos e, refazendo a trilha da antropologia que entende "raça" como construção social, além das discussões com esse grupo de antropólogos de várias procedências e tendências, pude me reconciliar com o ideário modernista.

O resultado daquele programa foi como uma retomada do Projeto da Unesco, pois brasileiros e estrangeiros se uniram para pesquisar temas que já estavam esquecidos de nossa literatura sociológica. Naquela altura não se falava em cotas e os pesquisadores descobriram muitas outras dimensões de identidade entre seus "nativos". Na introdução do livro Raça como retórica (Maggie e Rezende, 2002), que traz alguns resultados desse programa, sinalizei a necessidade de pensar, como na tradição modernista, a contribuição do Brasil para engrandecer e enriquecer a civilização. ${ }^{30}$

Também organizamos no IFCS, de 1998 a 2000, o Programa Cor e Educação e fizemos um levantamento completo do que estava sendo pensado e realizado como política pública para diminuir as desigualdades raciais. Descobrimos então que o Brasil ainda se pensava misturado. A maioria dos nossos entrevistados ainda achava que $\mathrm{O}$ sistema de cotas não era a melhor solução para enfrentar o racismo. Fizemos um estudo de caso de um movimento social que começava a ganhar, a cada dia, mais e mais adeptos, o Pré-Vestibular para Negros e Carentes (PVNC). Este estudo indicou que a estratégia de nomear os negros ao lado dos carentes representava uma maneira de reconhecer a questão "racial" sem deixar de falar nas desigualdades sociais e de classe. O movimento do PVNC propunha outro caminho para superar as nossas iniqüidades sociais. Voltarei ao tema do PVNC mais adiante, mas é preciso dizer que, quando apresentamos o resultado dessa pesquisa no ano de 2000, o campo estava minado e tudo estava sendo tratado com um tom moral e acusatório. Já era muito difícil recolocar o modernismo no seu lugar. Os números das desigualdades entre "negros" e "brancos" tinham ganho a mente dos bem-pensantes e da mídia que agora pareciam se mostrar a favor de uma estratégia que incluísse a reserva de lugares para negros. Para eles, a nossa sociedade deixava de ser o lugar da mistura e do híbrido para ser entendida como dividida nitidamente entre negros e brancos.

Se a tradição da antropologia fazia com que buscássemos auscultar o que dizem os nossos nativos sobre o tema da "raça", os proponentes dessa outra versão menos macunaímica e menos antropofágica de nossa cultura baseavam-se em que fontes?

Em artigo intitulado "Silêncio nunca mais", a jornalista Miriam Leitão revelou as fontes que a fizeram se convencer de que era preciso mudar o paradigma e que o caminho seriam as cotas. Diz ela:

As cotas são mesmo polêmicas. Eu sou a favor. Achei mais convincentes os dados de Roberto Martins e Ricardo Henriques e os argumentos de tantos negros que ouvi que provam que políticas universalistas não conseguiram, durante os últimos cem anos, enfrentar a distância entre pretos e pardos, de um lado, e brancos, de outro. Li os textos de especialistas como Antonio Alfredo Guimarães e Hélio Santos, vi o quadro de Nelson Valle e Silva que compara salários de negros e brancos no mesmo extrato social. Conversei com a governadora Benedita sobre os talentos que ela achou na montagem do governo e que estavam escondidos, por serem negros. Fui a debates como os do professor Hédio Silva, na PUC de São Paulo; do exministro Raul Jungman, na Fiesp; da ONU; da Cândido Mendes. Entrevistei negros, brasileiros e estrangeiros. Abri minha mente e deixei entrar a força das convicções de quem estudara ou vivera o problema. As cotas não são as únicas ações afirmativas, mas elas têm a força de empurrar o debate. Ação afirmativa é um campo amplo no qual políticas públicas, ações privadas podem começar a construção de menos desigualdade étnica no Brasil (O Globo, 22/12/2002).

Miriam Leitão apresentou de forma muito clara o que pensam aqueles que foram convenci- 
dos pelos números de Roberto Martins e Ricardo Henriques:

O racismo brasileiro é diferente do americano, mas tem sido muito eficiente em apartar as duas metades da população brasileira. Por não ter ocorrido aqui a grosseria da política de segregação, nos conformamos com um quadro de injustiça intolerável. E nos iludimos com o discurso de que o Brasil se miscigenou e, assim, dissolveu o problema. Da miscigenação, nossos álbuns familiares são testemunhas. O truque do racismo brasileiro foi não exigir atestado de origem. Foi dar aos brancos de pele mais chances, mais portas abertas, mais ascensão, mais poder ( $O$ Globo, 22/12/2002; grifos meus).

Nessa versão nossa nação é descrita como constituída de duas metades estanques. Embora Miriam Leitão reconheça que nossos álbuns de família estejam recheados dessa mistura, acredita que eles são fruto de um "truque", de um ilusionismo e, dizendo isso, põe abaixo aquilo que estava no cerne da utopia modernista. O Brasil, de Mário de Andrade, traçara um caminho próprio depois de comer o bispo Sardinha. Agora, segundo esta versão da nossa nação, é preciso jogar a estratégia do encontro e da mistura fora e adotar outra baseada no que Miriam Leitão está chamando de atestado de origem. Uma gota de sangue negro...? Quem sobraria para aplicar as cotas?

Há uma contradição que aparece no discurso de Miriam Leitão e em muitos outros. Se, de um lado, falam em um país dividido entre brancos e negros, de outro, não contestam o que chamam de miscigenação ou mistura dos nossos álbuns de família. O que Mirian Leitão propõe então é uma mudança radical na nossa concepção de nação, na qual os indivíduos buscarão um atestado de origem. Mas e o que fazemos então com aquela mistura que está nos nossos álbuns?

O próprio presidente Fernando Henrique Cardoso, em 1996 no seminário organizado pela Secretaria de Direitos da Cidadania do Ministério da Justiça, exortava os pesquisadores a descobrirem uma saída criativa e nossa para o problema:
Nós, no Brasil, de fato convivemos com a discriminação, convivemos com o preconceito, mas "as aves que aqui gorjeiam, não gorjeiam como lá" o que significa que a discriminação e o preconceito que aqui temos não são iguais aos de outras formações culturais.

Portanto, nas soluções para esses problemas, não devemos simplesmente imitar. Temos de ter criatividade, temos de ver de que maneira a nossa ambigüidade, essas características não cartesianas do Brasil - que dificultam tanto em tanto aspectos -, também podem ajudar em outros aspectos... É melhor, portanto, buscarmos uma solução mais imaginativa (Cardoso, 1997, p. 14).

Em outro discurso, por ocasião do dia mundial de combate ao racismo em 2000, mudava o rumo da conversa e propunha:

Este ano de 2001 é especialmente importante na luta contra a discriminação racial. Em agosto, a comunidade internacional realizará na África do Sul uma conferência mundial contra o racismo, a xenofobia e a intolerância, em que se avançará no diagnóstico das manifestações contemporâneas do racismo, discutindo suas causas, identificando suas vítimas e analisando estratégias para seu combate e superação. O Governo e o povo brasileiro estão engajados nesse combate. Resta muito a fazer para a plena superação do racismo no Brasil. Não é fácil desmantelar estruturas mentais e institucionais fortalecidas durante séculos de escravidão, exclusão social e visões românticas de "democracia racial". No entanto, muito já tem sido feito. Medidas como a reforma dos parâmetros curriculares e o reforço da fiscalização contra a discriminação no mercado de trabalho exemplificam o empenho de meu Governo nessa luta. Mas é importante que essas medidas continuem a se multiplicar, que tenham seguimento, e que a sociedade e os meios de comunicação reflitam com veracidade e com orgulho o fato de que somos realmente uma nação multi-étnica e multicultural. Nossa identidade mestiça é, sem dúvida, um dos aspectos centrais das realizações históricas que celebramos com os 500 anos do Descobrimento. ${ }^{31}$

Uma nação multi-étnica e multicultural e mestiça é uma contradição em termos. Ou somos multi-étnicos ou somos misturados. Assim, voltando ao argumento da jornalista Miriam Leitão, como dizer 
que nossos álbuns de família revelam as nossas mistura se vivemos numa sociedade só de negros e de brancos?

Certo ou errado nosso mito de origem fala que nós, brasileiros, somos um povo que veio de três "raças" diversas que aqui se uniram para plantar uma nova civilização. Macunaíma é o herói sem caráter porque estamos ainda, como disse Mário de Andrade lá pelos idos de 1928, como meninos de 20 anos buscando a nossa identidade. Como fazer para lançar esse mito por terra? Teríamos que reinventar o mito de Macunaíma e fazer como na brincadeira séria de Richard Morse (1990) um herói com bastante caráter?

Não se pode tomar as categorias empregadas nas estatísticas oficiais como representação social de toda a sociedade porque são, na verdade, um modelo construído pelos analistas a partir das realidades vivenciadas de muitas maneiras no cotidiano da vida social. Essa realidade do modelo não está contida na mente dos que vivem as realidades cotidianas. No entanto, o risco é que afirmando como verdade universal esse modelo analítico ele pode acabar fazendo parte da vida cotidiana e pode, ao fim e ao cabo, reinventar mesmo as representações sociais, como profecia que se cumpre por si mesma.

\section{Quem tem medo de mudar?}

É evidente que os alarmantes números das desigualdades "raciais" indicam um racismo renitente no Brasil. Mas como tentar extirpar esse mal? Os proponentes das cotas acham que temos de abandonar o ideário modernista, tratando-o como "truque". Mas eles vão realmente nos levar a superar nossas iniqüidades? Eis a minha dúvida.

Para encontrar uma solução mais interessante, é preciso fazer como Mário de Andrade e sair dos números que nos dão uma fotografia em preto e branco, e nem isso, porque as estatísticas não revelam os muitos tons de cinza que fotos em preto e branco contêm. As estatísticas não são como filmes que revelam a diacronia, as cores e as va- riações das formas. As estatísticas são modelos construídos que é preciso rechear de sangue, carne e músculo. Para buscar entender o que os números não podem revelar, aquilo que fundamenta nossa vida cotidiana, a saída é escutar e saber ouvir os muitos negros, brancos, morenos e pobres que serão afetados por esta mudança proposta, que sem dúvida alguma não custará muito para os próprios proponentes. Nosso país tem de buscar a inclusão de quase $80 \%$ da população que está fora de muitos importantes ganhos da cidadania. É preciso ir mais fundo para buscar as soluções que afetarão os sujeitos dessa história, e não se deve esquecer que para isso há muito a fazer para incluir milhares de jovens que ainda não conseguem terminar sequer o ensino fundamental.

Foi isso que fez um grupo de jovens pobres da periferia do Rio de Janeiro unindo-se em um movimento intitulado Pré-Vestibular para Negros e Carentes (PVNC) que citei mais acima. Acho que há aí uma pista que não deveria ser perdida. O movimento conseguiu atrair centenas de jovens que, beneficiados pelas políticas de inclusão universais, conseguiram terminar o ensino médio e queriam ter acesso a vagas nas universidades públicas do Rio de Janeiro. É preciso dizer que ainda são poucos os que terminam essa fase do percurso escolar. Apenas 30\% da faixa etária de jovens conseguem chegar ao fim do ensino médio. Esse grupo de jovens das periferias e dos bairros pobres da cidade, muito ativo, não queria ser cooptado por ideologias das agências financiadoras nacionais ou estrangeiras. Não aceitava apoio de qualquer fonte a não ser dos professores que davam aulas gratuitamente, ou na forma de empréstimos de salas de aula em igrejas ou associações de moradores e até, algumas vezes, de escolas da rede pública. Queriam discutir entre si e desenvolver uma estratégia criada por eles mesmos. Durante alguns anos conseguiram atrair não só militantes que se autoclassificavam como negros, mas também muitos brancos pobres e outros color blind, como um dos alunos que respondeu a um survey realizado pela minha equipe de pesquisa em 1994 se definindo como flicts, em referência à belíssima história de Ziraldo (1984).32 
Este movimento teve um enorme sucesso de mídia e seduziu muitos jovens estudantes que buscaram aquelas salas desconfortáveis tanto para aprender como para ensinar. Nomeando os negros ao lado dos carentes, o movimento conseguiu dar uma solução racialmente não neutra e ao mesmo tempo ser sensível às muitas maneiras que esses estudantes têm de se autoclassificarem. A eficácia do movimento deve-se certamente à garra desses jovens que buscavam sair do caminho das balas da polícia e dos traficantes e do isolamento em que se encontravam por estarem fora das possibilidades de competir com seus colegas mais bem-aquinhoados pela fortuna e herança educacional. Ao longo da década de 1990, desde a sua inauguração em uma paróquia de São João de Meriti e sob a liderança de frei Davi, o movimento cresceu de forma espetacular. Muitos Núcleos, como são chamados os grupos que se reúnem em igrejas, associações de moradores ou escolas, foram sendo criados e seus coordenadores, organizados em uma direção geral, discutiam constantemente os rumos do PVNC.

Até o ano da conferência de Durban em 2001, a maioria dos coordenadores era contrária à introdução de cotas. Suas lideranças queriam que os estudantes conseguissem por mérito e esforço próprios galgar um lugar no sistema de ensino superior e com isso talvez terem mais chances de sair dessas periferias nas quais a presença do Estado é quase nenhuma e onde os jovens estão à mercê de um outro "movimento": "o movimento" que no dizer popular significa o tráfico de drogas.

Depois de Durban, com a introdução da política de cotas para negros nas universidades públicas estaduais do Rio de Janeiro, o PVNC passou por uma transformação muito importante. Algumas de suas lideranças tiveram o seu ânimo diminuído e muitas abandonaram o movimento atormentados com dúvidas sobre o caminho a seguir. No dizer de uma ex-coordenadora: "A mudança gerou dúvida e intranqüilidade. Se de um lado, quem sabe, diminuiremos as desigualdades, com essa política, de outro lançaremos por terra o mérito". Finalmente, disse ela: "a dúvida maior é: como combater o racismo usando a raça?" 33 A maior transformação não veio, no entanto, dos que arrefeceram o ânimo, mas das propostas feitas por frei Davi. Esse padre dominicano que é um dos heróis fundadores do PVNC criou uma outra organização, o Educafro, que se define como um movimento para afrodescendentes e carentes e que ao contrário do PVNC aceitou doações de agências estrangeiras, rompendo com a proposta de autonomia financeira. Situando agora os carentes ao lado daqueles que têm origem africana afro - como critério de escolha de seus estudantes, o Educafro redefiniu os rumos do PVNC. Frei Davi organizou o Educafro como uma franquia, buscando seduzir os muitos núcleos do PVNC que quisessem se identificar com a proposta que acabou vitoriosa também neste movimento: a descendência deve ser tomada como base para a autoclassificação. Assim, aqueles que não quiserem excluir os mais brancos de seu álbum de família, certamente estarão excluídos dos cursinhos.

Que não se acuse Mário de Andrade de racista! Foi a sua geração e sob sua liderança que se iniciou o movimento mais radicalmente anti-racista depois de séculos de racismo dito científico. Mas talvez os que estão propondo o fim do ideário modernista sejam, no fundo, mais crentes em $\mathrm{Macu}$ naíma e no Manifesto antropófago do que a autora destas linhas. Talvez acreditem que comeremos o multiculturalismo hoje como o bispo Sardinha e não avaliam os riscos para a estrutura quando eventos como esses que descrevi mais acima ocorrem. Como disse Marshall Sahlins (2004), a estrutura corre riscos ao ser invadida pelos eventos que mesmo sendo interpretados à luz da tradição podem transformá-la de forma radical.

As mudanças estruturais produzidas pelas leis e normas exaradas pelo Estado, que descrevi aqui, ou seja, a criação de uma engenharia social baseada na bipolaridade racial, afetará muito mais a população misturada e flicts que vive nos imensos subúrbios e periferias das cidades. Mas como disse Miriam Leitão, todos nós estamos juntos nisso. Quem se responsabilizará pelas conseqüências?

Muitas pessoas que leram versões iniciais deste trabalho me perguntaram o que fazer então? Res- 
pondo sempre que há muito o que fazer para combater o racismo e as desigualdades no nosso país e que já não é sem tempo de começar. A primeira providência para qualquer campanha anti-racista deveria certamente começar, como muitos vêm dizendo desde o início deste debate, por destruir a própria idéia que o faz nascer: a idéia de "raça".

\section{NOTAS}

1 A Assembléia Estadual do Rio de Janeiro instituiu as cotas para as universidades do Estado em 2000. A primeira lei de cotas raciais instituía $40 \%$ de vagas para estudantes que se auto-declarassem negros/pardos. A lei foi modificada em 2003, e os candidatos agora têm que ser pobres em primeiro lugar e há 20\% de cotas para negros (e não mais negros/pardos). Sobre as normas do vestibular nas universidades do Estado do Rio de Janeiro implantadas por força de lei, ver a tese de doutorado de Elielma Ayres Machado (2004) e o artigo de Carla Ramos (2004), que está concluindo sua dissertação sobre o tema. Peter Fry vem chamando a atenção para essa criação do racismo a partir de leis e normas racializadas, ver, mais especificamente, Fry (2003).

2 Maggie e Fry (2002 e 2004) analisaram esta questão descrevendo as representações sobre cor e raça assim como mérito e esforço próprio.

3 Em Medo do feitiço levantei essa hipótese quando discuti as acusações de feitiçaria no Brasil Republicano (ver Maggie, 1992).

4 III Conferência Mundial das Nações Unidas de Combate ao Racismo, Discriminação Racial, Xenofobia e Intolerância Correlata.

5 O projeto da Unesco, como ficou conhecido, foi realizado a partir das propostas de Artur Ramos, representante brasileiro nesta organização, depois do fim da Segunda Guerra Mundial, e substituído por Luiz Aguiar da Costa Pinto por ter falecido precocemente. Costa Pinto propôs que o escopo da pesquisa fosse ampliado para incluir todo o Brasil e não só a Bahia como originalmente estava previsto. A idéia era justamente desvendar o que se pensava ser uma cultura que tinha resolvido de forma não violenta as suas diversidades étnicas. Marcos Chor Maio tem um importante trabalho no qual descreve todo os trâmites dessa história e discute as obras que resultaram desse esforço de pesquisa (ver Maio, 1997).

6 Tenho trabalhado com Peter Fry há muitos anos desde que estreitamos a nossa amizade por ocasião da defesa de minha dissertação de mestrado nos anos de 1970. Além de amigo, Peter Fry foi meu orientador na tese de doutorado e vem sendo desde então um interlocutor com o qual venho repartindo angústias e descobertas. As idéias aqui expressas foram discutidas com ele em inúmeras e constantes conversas e discussões formais e informais.

7 A palavra "raça" estará sempre entre aspas para frisar o fato de que é categoria nativa e não conceito, pois a moderna ciência da genética já destruiu as bases científicas em que a palavra foi alicerçada no século XIX.

8 Agradeço a Everardo Rocha os comentários que me incentivaram a persistir nesta investigação sobre os rumos do ideário modernista.

9 Gilda de Mello e Souza em o Tupi e o alaúde ([1979] 2003) faz uma das mais belas leituras do romance e vê a sua estrutura também toda feita da mistura, do bricolage. Lendo esse livro recentemente reeditado fiquei ainda mais impressionada, porque a autora de forma clara e precisa mostra como o livro é uma meditação "extremamente complexa sobre o Brasil". A leitura que a autora propôs "é menos a de uma interpretação triunfal e retoma a indicação pessimista de Mário [...]". Certamente a afirmação que vejo no romance não é de modo algum incompatível com essa visão ambivalente. Afinal, foi na nossa cultura mestiça, misturada e ambígua que, como mostrou Gilda de Mello e Souza, Mário foi beber, mesmo estando também mergulhado na cultura mais cosmopolita e universal.

10 Monoel Luiz Salgado Guimarães tem uma importante contribuição para a discussão desse livro fundador da historiografia brasileira (ver Guimarães, 2000).

11 O livro clássico de Mário de Andrade tem sido interpretado por muitos quando se discute a questão racial por ser mesmo um paradigma dessa versão de 
uma brasilidade mesclada de brancos, negros e índios. Lílian Schwarcz discutiu o assunto em duas ocasiões: se na primeira, em 1995, defendeu o mito dos ataques daqueles que o interpretavam como mentira, falsa consciência, na segunda, em 1998b, optou por um outro caminho tentando conciliar o mito com os dados das desigualdades raciais. Discordo de sua última interpretação, porque vejo o mito ou a fábula das três raças e a própria idéia de democracia racial como um ideal, algo que se busca, como uma vontade e um desiderato. Esse desejo de igualdade, esse sonho é uma forma toda nossa de combater o racismo ou poderia ser a nossa contribuição particular a esta luta pelo fim do racismo. Neste artigo tento enunciar os argumentos que me levam a pensar de forma diferente.

12 Agradeço a Lilia Schwarcz a leitura generosa e cuidadosa de uma primeira versão deste artigo. Seus comentários ajudaram-me a repensar a história do nosso mito de origem e as heranças do século XIX que marcaram a construção do "herói de nossa gente".

13 O estudo mais completo que rediscute Casagrande E senzala, apresentando uma análise complexa dessa obra é o de Araújo (1994). É preciso também discutir a expressão democracia racial que foi muitas vezes atribuída a Gilberto Freire e, segundo Guimarães (2002), foi cunhada mais tarde, por Roger Bastide e não em no livro de Gilberto Freyre.

$14 \mathrm{O}$ conde Arthur de Gobineau foi embaixador francês no Brasil e escreveu, em meados do século XIX, o Ensaio sobre a desigualdade das raças (1853-1855). Nos anos em que permaneceu no Brasil como chefe da delegação diplomática, segundo relato minucioso de Lilia Schwarcz "parecia respeitar apenas o imperador do Brasil [...] todos os demais na opinião desse embaixador francês, 'pareciam-se como macacos"' (Schwarcz, 1998b, p. 372). O conde Gobineau tinha uma visão pessimista sobre a miscigenação, para ele sinal de degeneração que fazia com que não houvesse futuro para nosso país. Lilia Schwarcz (1993) discutiu a obra de Gobineau e o debate que se travava entre pensadores daquela época em $O$ espetáculo das raças. Segundo a autora, as idéias de Gobineau repercutiram mais no Brasil do que no exterior.
15 É preciso também ler Schwarcz (1999) sobre a importância de Casa-grande E senzala para a interpretação da sociedade brasileira. Diz Schwarcz: "O 'cadinho de raças' aparecia como uma versão otimista, mais evidente aqui do que em qualquer outro lugar: 'Todo o brasileiro, mesmo o alvo, de cabelo louro, traz na alma quando não na alma, e no corpo, a sombra, ou pelo menos a pinta, do indígena e/ou do negro', afirmava Freire fazendo da mestiçagem uma questão ao mesmo tempo nacional e distintiva" (Schwarcz, 1999, p. 276).

16 Para uma análise do pensamento racial no século XIX, ver Schwarcz (1993).

17 Ver a Mulata de Di, Cavalcanti de 1928 no site www.dicavalcanti.com.br/, que apresenta toda a obra do pintor.

18 Ver o Abapurú de 1928 e a Negra de 1923, de Tarsila, no site www.tarsiladoamaral.com.br/.

19 Cf. canções de Caetano Veloso, "Haiti" e "Americanos".

20 O artista plástico Luiz Alphonsus, da geração Conceitual, só para citar um deles, fez dois trabalhos que remetem a esta influência modernista. $O$ conceitual caboclo e Índia e mato fazem parte da coleção Gilberto Chateaubriand.

21 Ver o livro de fotos de Hermano Vianna, que refez uma das viagens de Mário de Andrade (Vianna, 2000).

22 Esse seminário, organizado pelo Departamento de Direitos da Cidadania do Ministério da Justiça, teve a maioria das comunicações reunidas em livro organizado por Souza (1997).

23 Monica Grin (2000) discutiu esse evento e as várias posições em jogo em excelente análise em sua tese de doutorado.

24 Recentemente uma polêmica surgiu ao ser introduzido um método novo de identificação de candidatos que optaram pelas cotas no vestibular da UnB. Para uma discussão da questão, ver Maio e Santos (no prelo).

25 Para os que se posicionam a favor da política de cotas raciais, elas se constituem em um caminho mais curto para uma consciência racial que está 
ausente e deve ser reforçada. Eduard Telles (2004) afirma que este atalho é necessário para a diminuição das desigualdades raciais na educação. Fry (2005a), em resenha ao livro de Telles, pergunta se esse não seria um caminho sem volta e se a destruição da noção de democracia racial como ideal não é uma forma de jogar fora o bebê com a água do banho.

26 José Murilo de Carvalho (2004) em recente artigo chamou a atenção para o genocídio estatístico dos pardos que vem ocorrendo na divulgação dos dados sobre desigualdades raciais. O autor descreve como a questão vem sendo tratada a partir do século XIX nos censos demográficos e argumenta que esta mudança atual significa uma reviravolta na nossa concepção de nação.

27 Ver, por exemplo, Peter Fry (1983), Roberto DaMatta (1987b), Manuela Carneiro da Cunha (1985).

28 Ver DaMatta (1987a).

29 Cito aqui alguns desses trabalhos que partiram dos dados recolhidos ao longo do ano do centenário da Abolição da Escravatura: Schwarcz (1990), Birman (1990, 1997), Damasceno (1997), Cavalcanti (1997), Farias (1997), Moutinho (1997) e Maggie (1989).

30 Ver em Maggie e Rezende (2002) uma seleção dos ensaios produzidos por pesquisadores que participaram do Programa e que também revisitaram o tema com pesquisas tanto no Brasil quanto no estrangeiro.

31 Mensagem do presidente da República por ocasião do Dia Internacional pela Eliminação da Discriminação Racial (21/3/2001, www.mj.gov.br, grifos meus).

32 Ver Maggie (2001).

33 Uma estudante universitária ex-coordenadora de um Núcleo do PVNC e agora estudante de ciências sociais.

\section{BIBLIOGRAFIA}

ANDRADE, Mário de. (1984 [1928]), Macunaíma: o herói sem nenbum caráter. Belo Hori-
zonte/Brasília, Itatiaia/Instituto Nacional do Livro/Fundação Pró-Memória.

. (2001), Macunaíma: o herói sem nenhum caráter. 32 ed. Texto revisto por Telê Porto Ancona Lopez. Belo Horizonte/Rio de Janeiro, Livraria Garnier (Coleção dos Autores Modernos da Literatura Brasileira)

ANDRADE, Mário de \& BANDEIRA, Manuel. (1974), Itinerários: cartas a Alphonsus de Guimaraens Filho. Rio de Janeiro, Duas Cidades.

ANDRADE, Oswald. (1978), Do pau-brasil à antropofagia e às utopias. Rio de Janeiro, Civilização Brasileira.

ANDREWS, George Reid. (1997), "Ação afirmativa: um modelo para o Brasil", in Jessé Souza (org.), Multiculturalismo e racismo: uma comparação Brasil-Estados Unidos, Brasília, Paralelo 15.

ARAÚJO, Ricardo Benzaquem de. (1994), Guerra e paz: Casa-grande E senzala e a obra de Gilberto Freyre nos anos 30. Rio de Janeiro, Editora 34.

BANDEIRA, Manuel. (s./d.), Apresentação da poesia brasileira. Rio de Janeiro, Ediouro (col. Prestígio).

BIRMAN, Patrícia. "Beleza negra". (1990), Cadernos Candido Mendes, Estudos Afro-Asiáticos, 18, Rio de Janeiro.

(1997), "Maio de 1988 - outras histórias", in Contins, Marcia (org.), Quase catálogo n. 6: visões da abolição, Rio de Janeiro, Ciec/ECO/UFRJ/Museu da Imagem e do Som/Secretaria de Cultura e Esporte.

BOAS, F. (1986), Anthropology and modern life. Nova York, Dover Publications.

BOURDIEU, Pierre \& WACQUANT, Loic. (1998), "Les ruses de la raison impérialiste". Actes de la Recherche en Sciences Sociale, 121-122: 109-118. 
CARDOSO, Fernando Henrique. (1997), "Pronunciamento do presidente da República na abertura do Seminário Multiculturalimo e Racismo", in Jessé Souza (org.), Multiculturalismo e racismo: uma comparação Brasil-Estados Unidos, Brasília, Paralelo 15.

. (2001), "Mensagem do presidente da República por ocasião do Dia Internacional pela Eliminação da Discriminação Racial”, 21 mar.

CAVALCANTI, Maria Laura Viveiros de Castro. (1997), "A temática racial no carnaval carioca: algumas reflexões", in Contins, Marcia (org.), Quase catálogo n. 6: visões da abolição, Rio de Janeiro, Ciec/ECO/UFRJ/Museu da Imagem e do Som/Secretaria de Cultura e Esporte.

CARVALHO, José Murilo. (2004), "Genocídio racial estatístico”. O Globo, 27 dez., p. 7.

CUNHA, Manuela Carneiro da. (1985), Negros estrangeiros: os escravos estrangeiros e sua volta à África. São Paulo, Brasiliense.

DAMASCENO, Caetana. (1997), "Campanha da fraternidade de 1988: ou a 'fábula das três raças revisitada', in Contins, Marcia (org.), Quase catálogo n. 6: visões da abolição, Rio de Janeiro, Ciec/ECO/UFRJ/Museu da Imagem e do Som/Secretaria de Cultura e Esporte.

DaMATTA, Roberto. (1987a), A casa e a rua. Rio de Janeiro, Guanabara.

(1987b), Relativizando: uma introdução à antropologia social. Rio de Janeiro, Rocco.

. (1989), O que faz o Brasil, Brasil? Rio de Janeiro, Rocco.

. (1997), "Notas sobre o racismo à brasileira", in Jessé Souza (org.), Multiculturalismo e racismo: uma comparação BrasilEstados Unidos, Brasília, Paralelo 15.
FARIAS, Patrícia. (1997), "Festa, nação, etnia, personalidade: notícias da abolição", in Contins, Marcia (org.), Quase catálogo n. 6: visôes da abolição, Rio de Janeiro, Ciec/ECO/UFRJ/Museu da Imagem e do Som/Secretaria de Cultura e Esporte.

FERNANDES, Florestan. (1965), A integração do negro na sociedade de classe. São Paulo, Companhia Editora Nacional.

FREYRE, Gilberto. ([1933] 1995), Casa-grande E senzala: formação da família brasileira sob regime da economia patriarcal. Rio de Janeiro, Record.

FRY, Peter. (1983), "Feijoada e soul food", in Para inglês ver, Rio de Janeiro, Zahar.

. (1995a), "O que a Cinderela Negra tem a dizer sobre a 'política racial' no Brasil". Revista USP, 28: 122-135.

. (1995b), "Why Brazil is different". Times Literary Supplement, 6-7.

. (2000), "Politics, nationality and the meanings of 'race' in Brazil". Daedalus, 129.

(2001), "Feijoada e soul food 25 anos depois", in Neide Esterci, Peter Fry e Mirian Goldenberg (orgs.), Fazendo antropologia no Brasil, Rio de Janeiro. DP\&A Editora.

(2003), "Introduzindo o racismo". O Globo, 21 mar.

. (2004), "Culturas da diferença: seqüelas das políticas coloniais portuguesas e britânicas na África Austral. Afro-Ásia, 29/30: 271-316, Salvador.

. (2005a), "Over the rainbow". Times L $i$ terary Supplement, 5313: 27-27.

. (2005b), A persistência da raça: ensaios antropológicos sobre o Brasil e a África Austral, Rio de Janeiro, Civilização Brasileira. 
GILLIAM, Angela. (1997), "O ataque contra as ações afirmativas nos EUA: um ensaio sobre o Brasil", in Jessé Souza (org.), Multiculturalismo e racismo: uma comparação Brasil-Estados Unidos, Brasília, Paralelo 15.

GOBINEAU, Arthur de. (1853-1855), Essai sur l'inegualité des races humaines. Paris, F. Didot.

GÓES, José Roberto Pinto de. (2004), "O racismo vira lei”. O Globo, Caderno 1, Opinião, Rio de Janeiro, 15 ago.

GOLDWASSER, Maria Julia. (1975), O palácio da samba: estudo antropológico da escola de samba Estação Primeira de Mangueira. Rio de Janeiro, Zahar.

GRIN, Monica. (1998), "Descompassos \& dilemas morais: percepções sobre a questão racial no Brasil". Seminário Fronteiras e Interseções, Universidade Estadual de Campinas.

(2000), O desafio multiculturalista.

Tese de doutorado no Instituto Universitário de Pesquisa do Rio de Janeiro.

GUIMARÃES, Antonio Sérgio. (1997), "A desigualdade que anula a desigualdade: notas sobre a ação afirmativa no Brasil", in Jessé Souza (org.), Multiculturalismo e racismo: uma comparação Brasil-Estados Unidos, Brasília, Paralelo 15.

. (2002), Classes, raças e democracia. São Paulo, Editora 34.

GUIMARÃES, Manoel Luiz Salgado. (2000), "História e natureza em Von Martius: esquadrinhando o Brasil para construir a nação". Revista de História, Ciências, Saúde-Manguinhos, 7 (2), jul.-out.

HANCHARD, Michael. (1996), "'Americanos', brasileiros e a cor da espécie humana: uma resposta a Peter Fry". Revista USP, set.out.-nov.
HASENBALG, Carlos. (1979), Discriminação e desigualdades raciais no Brasil. Rio de Janeiro, Graal.

. (1987), "O negro às vésperas do centenário". Cadernos Candido Mendes, Estudos Afro-Asiáticos, 13, Rio de Janeiro. (1997), "O contexto das desigualdades raciais", in Jessé Souza (org.), Multiculturalismo e racismo: uma comparação Brasil-Estados Unidos, Brasília, Paralelo 15.

HENRIQUES, Ricardo. (2002), "É preciso tratar desigualmente os desiguais". O Globo, 21 abr. Entrevista feita por Helena Celestino e Maiá Meneses (site O Globo, acesso 24 jul.).

HOLANDA, Sérgio Buarque de. ([1936] 1991), Raízes do Brasil. Rio de Janeiro, José Olympio.

KOCH-GRUNBERG, Theodor. (1917-1928), Von Roaima zum orinoco: ergebnisse einer reside in nofrd brasillien und Venezuela in den jabren 1911-1913. Berlim, D. Reiner (E.Vohsen).

LEITÃO, Miriam. (2002), "O silêncio nunca mais". O Globo, 22 dez, p. 4, Rio de Janeiro.

MACHADO, Elielma Ayres. (2004), Desigualdades "raciais" e ensino superior: um estudo sobre a introdução das leis de reserva de bagas para egressos de escolas públicas e cotas para negros, pardos e carentes na Universidade do Estado do Rio de Janeiro (2000-2004). Tese de doutorado. Rio de Janeiro, Programa de Pós-Graduação em Sociologia e Antropologia, IFCS/UFRJ.

MAGGIE, Yvonne. ([1975] 2001), Guerra de orixá: um estudo de ritual e conflito. Rio de Janeiro, Zahar.

- (1989), Catálogo do Centenário. Rio de Janeiro, Ciec/ECO/Associação Cultural de Estudos Contemporâneos/Núcleo da Cor/UFRJ. 
(1991), A ilusão do concreto: análise do sistema de classificação racial no Brasil. Tese para o concurso de professor titular de Antropologia, Rio de Janeiro, Departamento de Ciências Sociais da UFRJ.

(1992), Medo do feitiço: relações entre magia e poder no Brasil. Rio de Janeiro, Arquivo Nacional.

. (1998), "Cultura e preconceito: raça, identidade e diferença”, in Everardo Rocha (org.), Cultura \& imaginário: interpretação de filmes e pesquisa de idéias. Rio de Janeiro, Mauad.

. (2001), "Os novos bacharéis". Novos Estudos do CEBRAP, 52, São Paulo.

MAGGIE, Yvonne \& FRY, Peter. (2002), "Um debate que não houve”. Enfoques (revista eletrônica), Rio de Janeiro, Programa de Pós-Graduação em Sociologia e Antropologia.

(2004), "Cotas raciais: construindo um país dividido". Econômica, 6 (1): 153161, Rio de Janeiro.

MAGGIE, Yvonne \& REZENDE, Claudia Barcellos (orgs.). (2002), Raça como retórica: a construção da diferença. Rio de Janeiro, Civilização Brasileira.

MAIO, Marcos Chor. (1997), A bistória do Projeto Unesco: estudos raciais e ciências sociais no Brasil. Rio de Janeiro, Instituto Universitário de Pesquisa do Rio de Janeiro (Iuperj).

MAIO, Marcos Chor \& SANTOS, Ricardo Ventura. (no prelo), "Políticas de cotas raciais, os olhos da sociedade e os usos da antropologia: o caso do vestibular da Universidade de Brasília (UnB)". Revista Horizontes Antropológicos, Porto Alegre.

MARTIUS, Carl F. von. (1844), Como se deve escrever a história do Brasil. $1^{\text {a }}$ edição.
MARX, Anthony. (1997), "A construção da raça no Brasil: comparação histórica e implicações políticas", in Jessé Souza (org.), Multiculturalismo e racismo: uma comparação Brasil-Estados Unidos, Brasília, Paralelo 15.

MONTEIRO, Fabiano Dias. (2003), Retratos em branco e preto, retratos sem nenbuma cor: a experiência do disque-racismo da Secretaria de Segurança Pública do Estado do Rio de Janeiro. Dissertação de mestrado do Programa de Pós-Graduação em Sociologia e Antropologia do IFCS/UFRJ, Rio de Janeiro.

MORAES, Eduardo Jardim de. (1999), Limites do moderno: o pensamento estético de Mário de Andrade. Rio de Janeiro, Relume Dumará.

MORSE, Richard. (1990), A volta de Macunaima: cinco estudos solenes e uma brincadeira séria. São Paulo, Companhia das Letras.

MOUTINHO, Laura. (1997), "A força do mesmo: a comemoração na voz". in Contins, Marcia (org.), Quase catálogo n. 6: visões da abolição, Rio de Janeiro, $\mathrm{Ciec/ECO/UFRJ/Museu} \mathrm{da} \mathrm{Imagem} \mathrm{e} \mathrm{do}$ Som/Secretaria de Cultura e Esporte.

NOGUEIRA, Oracy. (1985), Tanto preto quanto branco: estudos de relaçôes raciais. São Paulo, T. A. Queiroz.

(1998), Preconceito de marca: as relações raciais em Itapetininga. São Paulo, Edusp.

OLIVEIRA, Lucia Helena Garcia; PORCARO, Rosa Maria \& ARAÚJO, Teresa Cristina N. de. (1983), "O lugar social do negro no mercado de trabalho", in Rosa Maria Porcaro e Teresa Cristina N. de Araújo, O lugar do negro na força de trabalho, Rio de Janeiro, IBGE.

PRADO, Paulo. ([1928] 1972), Retrato do Brasil: ensaio sobre a tristeza brasileira. Rio de Janeiro, José Olimpio. 
RAMOS, Carla. (2004), "Aluno no 1232/2004 - Indeferido. Entre classe e raça: um dilema brasileiro". VI Jornada Interna de pósgraduandos do PPGSA/UFRJ (mimeo.).

REIS, Fabio Wanderley. (1997), "Mito e valor da democracia racial", in Jessé Souza (org.), Multiculturalismo e racismo: uma comparação Brasil-Estados Unidos, Brasília, Paralelo 15.

SAHLINS, Marshall. (2004), "O retorno do evento, outra vez", in Cultura na prática, Rio de Janeiro, Editora da UFRJ.

SCHWARCZ, Lilia Moritz. (1990), "De festa também se vive: reflexões sobre o centenário da abolição em São Paulo". Cadernos Candido Mendes, Estudos Afro-Asiáticos, 18: 13-27, Rio de Janeiro. . (1993), O espetáculo das raças: cientistas, instituições e a questão racial no Brasil: 1870-1930. São Paulo, Companhia das Letras.

. (1995), "Complexo de Zé Carioca: notas sobre uma identidade mestiça e malandra". Revista Brasileira de Ciências Sociais, 29, ano 10, São Paulo.

. (1998a), As barbas do Imperador: D. Pedro II um monarca nos trópicos. São Paulo, Companhia das Letras.

(1998b), "Nem preto nem branco, muito pelo contrário: cor e raça na intimidade", in (org.), História da vida privada no Brasil. São Paulo, Companhia das Letras, 1998.

. (1999), "Questão racial e etnicidade", in Sergio Miceli (org.), O que ler na ciência social brasileira, São Paulo, Sumaré.

SILVA, Denise Ferreira da. (1999), "Zumbi \& Simpson, Farrakan \& Pelé: as encruzilhadas do discurso racial". Estudos Afro-Asiáticos, 33: 87-98.
SILVA, Nelson do Valle. (1978), Black-white income differentials: Brazil 1960. Ann Arbor, Michigan, University of Michigan.

SILVA, Nelson do Valle \& HASENBALG, Carlos. (1988), Estrutura social, mobilidade e raça. Rio de Janeiro, Vértice.

SKIDMORE, Thomas. (1997), "Ação afirmativa no Brasil? Reflexões de um brasilianista”, in Jessé Souza (org.), Multiculturalismo e racismo: uma comparação Brasil-Estados Unidos, Brasília, Paralelo 15.

SOUZA, Gilda de Mello. ([1979] 2003), O tupi e o alaúde. São Paulo, Duas Cidades.

SOUZA, Jessé (org.). (1997), Multiculturalismo e racismo: uma comparação Brasil-Estados Unidos. Brasília, Paralelo 15.

TELLES, Eduard E. (2004), Race in another America: the significance of skin color in Bra$z i l$. Princeton/Oxford, Princeton University Press.

TEIXEIRA, Moema de Poli. (1986), Familia e identidade racial: os limites da cor nas relações e representações de um grupo de baixa renda. Dissertação de Mestrado, Rio de Janeiro, Museu Nacional, Programa de Pós-Graduação em Antropologia Social da UFRJ.

(1998), Negros em ascensão social: trajetórias de alunos e professores universitários no Rio de Janeiro. Tese de doutorado, Rio de Janeiro, Programa de Pós-Graduação em Antropologia da UFRJ, Museu Nacional.

VELHO, Gilberto. (1971), A utopia Urbana. Rio de Janeiro, Zahar.

VIANNA, Hermano. (1995), O mistério de samba. Rio de Janeiro, Editora da UFRJ/Zahar. . (2000), Música do Brasil. Rio de Janeiro, Abril.

ZIRALDO. (1984), Flicts. São Paulo, Melhoramentos. 
Outras fontes (sub 2)

DIRETRIZES curriculares nacionais para a educação das relações étnico-raciais e para o ensino de História e Cultura afro-brasileira e africana. (2004), Brasília, DF, Secretaria de Políticas de Promoção da Igualdade Racial/Ministério da Educação, Secretaria de Educação Continuada, Alfabetização e Diversidade, Inep, jul. Ver no site www.observa.ifcs.ufri.br.

PORTARIA N. 30. (2004), Dispõe sobre procedimentos para inscrição e seleção dos candidatos ao processo seletivo do FIES referente ao segundo semestre de 2004 e dá outras providências. Brasília, Ministério da Educação, 12 ago. Ver no site www.observa.ifcs.ufri.br.

www.mi.gov.br/

www.dicavalcanti.com.br/

www.tarsiladoamaral.com.br/ 


\section{MÁRIO DE ANDRADE AINDA VIVE? O IDEÁRIO MODERNIS- TA EM QUESTÃO}

Yvonne Maggie

\section{Palavras-chave}

Ação afirmativa, Cotas, Ensino superior, Nação, Brasilidade modernista

Este trabalho busca refletir sobre a hipótese de que se inicia uma espécie de terremoto na maneira pela qual o Brasil pensa o Brasil no alvorecer do século XXI. Com a recente legislação sobre cotas para negros nas universidades e no serviço público federal, a idéia de nação misturada da "fábula das três raças" parece ter sido questionada cedendo lugar à noção de uma nação dividida entre negros e brancos. Pela primeira vez na nossa história desde os anos de 1920, a elite brasileira parece ter lançado por terra as bases do pensamento que permitiu a criação de nossa cultura mais radicalmente nacional e cosmopolita. O ideário de brasilidade modernista de Mário e Oswald de Andrade, de Paulo Prado e Sérgio Buarque de Holanda, de Gilberto Freire e Di Cavalcanti, de Tarsila do Amaral e Anita Malfati está sob suspeita. Qual o significado da mudança em nossa legislação, e como pode afetar a estrutura de nossa sociedade baseada em um sistema de valores que não aposta na oposição, mas na complementaridade, no que une e não no que separa?

\section{DOES MÁRIO DE ANDRADE STILL LIVE? THE MODERNIST IDEATION IN COGITATION}

Yvonne Maggie

\section{Keywords}

Affirmative action; Quotas; College education; Nation; Modernist brazilian

This paper reflects upon the hypothesis that a dramatic change is taking place in the way Brazil thinks about itself at the dawn of the 21st century. With the passage of recent laws on quotas for black people at public universities and the civil service, the notion of a mixed nation made up of "three races" seems to have been challenged, giving way to the idea of a nation divided between blacks and whites. For the first time in our history since the 1920 s, the Brazilian elite seems to have shattered the foundations of the idea that allowed for the creation of our most radically nationalistic and cosmopolitan culture. The notions of a Modernist Brazilian character forged by Mário and Oswald de Andrade, Paulo Prado and Sérgio Buarque de Holanda, Gilberto Freire and Di Cavalcanti, Tarsila do Amaral e Anita Malfati, is under suspicion. What does this change in our law mean, and how can it affect the structure of our society, based as it is in a set of values which does not emphasize opposition, but rather complementarity, giving precedence to that which unites rather than that which separates?

\section{MÁRIO DE ANDRADE VIT EN- CORE? LA DOCTRINE MODER- NISTE EN QUESTION}

Yvonne Maggie

\section{Mots-clés}

Action affirmative; Quotas; Éducation supérieure; Nation;

Brésilien moderniste

Cet article cherche a réflechir sur l'hypothèse selon laquelle il s'opère en ce moment une sorte de changement radical dans la manière dont le Brésil pense le Brésil à l'aube du $\mathrm{XXI}^{\mathrm{e}}$ siècle. Avec les lois récentes sur les quotas pour noirs dans les universités et la fonction publique, l'idée de cette nation mélangée de la "fable des trois races" semble avoir été remise en question, laissant la place au concept d'une nation partagée entre blancs et noirs. Pour la première fois dans notre histoire depuis les années 1920, l'élite brésilienne semble avoir jeté par terre les fondements de la pensée qui a permis la création de notre culture la plus radicalement nationale et cosmopolite. La notion d'un caractère brésilien moderniste de Mário et Oswald de Andrade, de Paulo Prado et Sérgio Buarque de Holanda, de Giberto Freire et Di Cavalcanti, de Tarsila do Amaral et Anita Malfati, est désormais vue avec méfiance. Que signifie ce changement dans notre législation, et de quelle façon peut-il influer sur la structure de notre société basée comme elle est sur de valeurs qui ne mettent pas l' accent sur l'opposition, mais plutôt sur la complementarité, et sur ce qui unit plutôt que sur ce qui sépare? 